\title{
Rhodotorula psychrophila sp. nov., Rhodotorula psychrophenolica sp. nov. and Rhodotorula glacialis sp. nov., novel psychrophilic basidiomycetous yeast species isolated from alpine environments
}

\author{
Correspondence \\ Rosa Margesin \\ rosa.margesin@uibk.ac.at
}

\author{
Rosa Margesin, ${ }^{1}$ Pierre-Alain Fonteyne, ${ }^{2}$ Franz Schinner $^{1}$ \\ and José Paulo Sampaio ${ }^{3}$
${ }^{1}$ Institute of Microbiology, Leopold Franzens University, Technikerstrasse 25, 6020 Innsbruck, Austria
${ }^{2}$ Scientific Institute of Public Health, Mycology Section, Rue Juliette Wytsman 14, 1050 Brussels, Belgium
${ }^{3}$ Centro de Recursos Microbiológicos, Secção Autónoma de Biotecnologia, Faculdade de Ciências e Tecnologia, Universidade Nova de Lisboa, 2829-516 Caparica, Portugal

\begin{abstract}
Three novel psychrophilic species of the genus Rhodotorula are described. Rhodotorula psychrophila sp. nov. (type strain $\mathrm{PB} 19^{\top}=\mathrm{CBS} 10440^{\top}=\mathrm{DSM} 18768^{\top}$ ), Rhodotorula psychrophenolica sp. nov. (type strain $\mathrm{AG} 21^{\top}=\mathrm{CBS} 10438^{\top}=\mathrm{DSM} 18767^{\top}$ ) and Rhodotorula glacialis sp. nov. (type strain $A 19^{\top}=$ CBS $10436^{\top}=D S M 18766^{\top}$ ) were isolated from soil collected from an alpine railway area, from mud in the thawing zone of a glacier foot and from glacier cryoconite, respectively. All three species have been assigned to the genus Rhodotorula on the basis of molecular sequence data and physiological and morphological properties. Rhodotorula psychrophila is not able to grow at temperatures above $15{ }^{\circ} \mathrm{C}$. Rhodotorula psychrophenolica and Rhodotorula glacialis degrade high concentrations of phenol (up to 12.5 and $5 \mathrm{mM}$, respectively) as the sole carbon source at $10^{\circ} \mathrm{C}$. Sequence analyses of the $26 \mathrm{~S}$ rDNA D1/D2 regions indicated that the novel species are phylogenetically related and belong to a clade that includes other psychrophilic yeasts.
\end{abstract}

\section{INTRODUCTION}

Members of the genus Rhodotorula are known for their ability to degrade phenolic compounds (Sampaio, 1999; Fell et al., 2001). They also colonize extreme environments (Sampaio, 2004). We have previously investigated lowtemperature degradation of phenol by cold-adapted basidiomycetous yeasts isolated from cold alpine environments (Margesin et al., 2003, 2005; Bergauer et al., 2005). According to the new classification of basidiomycetes provided by Bauer et al. (2006), the majority of the strains belonged to the class Microbotryomycetes of the subphylum Pucciniomycotina. Representatives of the genus Rhodotorula were characterized by a high metabolic versatility towards the utilization of a number of phenolrelated monoaromatic compounds as the sole carbon

Abbreviations: ITS, internal transcribed spacer; MYP, malt-yeastpeptone.

The GenBank/EMBL/DDBJ accession numbers for the 26S rDNA D1/ D2 and ITS sequences determined in this study are given in Table 1. source at $10{ }^{\circ} \mathrm{C}$ and were able to grow in the presence of high concentrations of these compounds (Bergauer et al., 2005). A group of strains from these previous studies remained unidentified to the species level. They showed no growth above $15{ }^{\circ} \mathrm{C}$ or $20{ }^{\circ} \mathrm{C}$ and could thus be classified as true psychrophiles. Morphological and physiological properties, as well as 26S D1/D2 and internal transcribed spacer (ITS) $5.8 \mathrm{~S} \mathrm{rDNA}$ sequences, indicate that these strains belong to hitherto unknown species. In this study, we describe three novel species of the genus Rhodotorula: Rhodotorula psychrophila sp. nov., Rhodotorula psychrophenolica sp. nov. and Rhodotorula glacialis sp. nov.

\section{METHODS}

Sample collection and isolation. Samples were collected from the following Alpine habitats: alpine glacier cryoconite from the Stubaier glacier near Innsbruck in Tyrol, Austria (altitude $2900 \mathrm{~m}$ above sea level; $46^{\circ} 59^{\prime} 12^{\prime \prime} \mathrm{N} 11^{\circ} 06^{\prime} 53^{\prime \prime} \mathrm{E}$ ); mud in the thawing zone of the glacier foot (glacier mud) collected from the Stubaier glacier, Austria, and the Etendard glacier near Grenoble, France (altitude $2900 \mathrm{~m}$ 
above sea level; $45^{\circ} 09^{\prime} 45^{\prime \prime} \mathrm{N} 06^{\circ} 10^{\prime} 00^{\prime \prime} \mathrm{E}$ ); soil and sediment samples from an oil-shale mine in Seefeld, Austria, and a railway area at the Brenner pass, at the border of Austria and Italy (Table 1). Yeasts were isolated as described previously (Margesin et al., 2002; Bergauer et al., 2005) and maintained on R2A agar (Difco) plates. Long-term storage was performed in $10 \%(\mathrm{w} / \mathrm{v})$ skimmed milk at $-80{ }^{\circ} \mathrm{C}$.

Physiological and biochemical characterization. Morphological, physiological and biochemical properties were determined according to Barnett et al. (2000). Additional assimilation tests using aromatic compounds were performed as described (Margesin et al., 2003; Bergauer et al., 2005). Assimilation of carbon and nitrogen compounds and growth requirements were tested at $15{ }^{\circ} \mathrm{C}$. The effect of temperature was examined at $1-30{ }^{\circ} \mathrm{C}$ (at $5{ }^{\circ} \mathrm{C}$ intervals) in liquid culture and on agar plates. Phenol degradation was determined in fed-batch cultures at $10{ }^{\circ} \mathrm{C}$ as previously described (Margesin et al., 2003, 2005).

Phylogenetic analysis. For DNA isolation, cells were harvested from 5-day-old subcultures and lyophilized. DNA was isolated by the CTAB (hexadecyltrimethylammonium bromide) method (O'Donnell et al., 1997). PCR products including ITS1, 5.8S and ITS2 were obtained by utilizing the forward primer $5^{\prime}$-GTCGCTACTACCCGATTGAATGGCT- $3^{\prime}$ and the reverse primer $5^{\prime}$-CCTCCGCTTATTGATATGCTTAAG- $3^{\prime}$. PCR products including the D1/D2 domain were obtained by utilizing the forward primer $5^{\prime}$-GCATATCAATAAGCGGAGGAAAAG-3' and the reverse primer $5^{\prime}$ CGCCAGTTCTGCTTACC-3'. A DyeTerminator Quick Start kit (CEQ8000; Beckman) was used for the sequencing reactions in a total volume of $20 \mu \mathrm{l}(1 \mu \mathrm{l}$ purified PCR product, $1 \mu \mathrm{l}$ of the forward or reverse primers used for PCR, $4 \mu \mathrm{l}$ Beckman CEQ DTCS Quick Start mix, $14 \mu$ MilliQ water) and samples were placed in a cycler for 35 cycles of $96{ }^{\circ} \mathrm{C}$ for $20 \mathrm{~s}, 50{ }^{\circ} \mathrm{C}$ for $20 \mathrm{~s}$ and $60{ }^{\circ} \mathrm{C}$ for $4 \mathrm{~min}$. Sequences were obtained with an automatic sequencer (Beckman CEQ8000; Beckman-Coulter, Inc.) and aligned with SeqMan (DNASTAR). The heuristic maximum-parsimony analysis was employed (100 rounds of heuristic search with TBR branch swapping, starting from trees obtained by random addition of sequences, MulTrees option on, deepest descent option off) and was validated using 1000 rounds of bootstrap analysis (Felsenstein, 1985).
Maximum-parsimony and bootstrap calculations used PAUP software (Swofford, 2001).

\section{RESULTS AND DISCUSSION}

\section{Phenotypic properties}

Eleven strains isolated from alpine glacier materials, soil or sediment samples, belonged to the genus Rhodotorula. Attempts to induce the sexual stage by incubating single or mixed cultures of each of the three novel species on cornmeal agar (CMA) at $15{ }^{\circ} \mathrm{C}$ for two months were always negative. The strains were characterized by the following properties (Barnett et al., 2000; Fell et al., 2001; Sampaio et al. 2003): absence of pigments (creamy-white colonies), vegetative reproduction by polar budding, no ballistoconidia, no fermentation, no myo-inositol assimilation but assimilation of D-glucuronate, no production of starch-like compounds, utilization of nitrate as a nitrogen source and utilization of aromatic compounds as sole carbon source (Table 2).

All strains investigated in this study could be classified as true psychrophiles (Morita, 1975). Members of Rhodotorula psychrophila sp. nov. were not able to grow at temperatures above $15{ }^{\circ} \mathrm{C}$, whereas representatives of the other two novel species could grow at temperatures of up to $20{ }^{\circ} \mathrm{C}$ (Table 2). In addition to variations in the maximum growth temperature, the three novel species differed in their abilities to utilize high concentrations of phenol as the sole carbon source (Table 2). The assimilation patterns of carbon and nitrogen compounds were almost identical. D-Melezitose was well assimilated by members of $R$. psychrophila sp. nov. and was not assimilated by members of $R$. psychrophenolica sp. nov.

Table 1. Rhodotorula strains examined by ITS $5.8 S$ and D1/D2 rDNA regions

$\mathrm{T}_{\max }$, Maximum growth temperature; A, Austria; F, France.

\begin{tabular}{|c|c|c|c|c|}
\hline \multirow[t]{2}{*}{ Strain } & \multirow[t]{2}{*}{ Source } & \multicolumn{2}{|c|}{ GenBank accession numbers } & \multirow[t]{2}{*}{$\mathrm{T}_{\max }\left({ }^{\circ} \mathrm{C}\right)$} \\
\hline & & ITS $5.8 S$ & D1/D2 & \\
\hline \multicolumn{5}{|l|}{ Rhodotorula psychrophila sp. nov. } \\
\hline PB19 ${ }^{\mathrm{T}}\left(=\right.$ CBS $10440^{\mathrm{T}}=$ DSM $\left.18768^{\mathrm{T}}\right)$ & Soil (railway area) (A) & EF151243 & EF151252 & 15 \\
\hline PB03 & Sediment (oil-shale mine) (A) & EF151244 & EF151253 & 15 \\
\hline PB15 (=CBS 10439) & Sediment (oil-shale mine) (A) & EF151245 & EF151254 & 15 \\
\hline \multicolumn{5}{|l|}{ Rhodotorula psychrophenolica sp. nov. } \\
\hline $\mathrm{AG} 21^{\mathrm{T}}\left(=\mathrm{CBS} 10438^{\mathrm{T}}=\mathrm{DSM} 18767^{\mathrm{T}}\right)$ & Mud at glacier foot $(\mathrm{F})$ & EF151246 & EF151255 & 20 \\
\hline $\mathrm{A} 12$ & Glacier cryoconite $(\mathrm{A})$ & EF151247 & EF151256 & 20 \\
\hline AG15 & Mud at glacier foot (A) & EF151248 & EF151257 & 20 \\
\hline \multicolumn{5}{|l|}{ Rhodotorula glacialis sp. nov. } \\
\hline $\mathrm{A} 19^{\mathrm{T}}\left(=\mathrm{CBS} 10436^{\mathrm{T}}=\right.$ DSM $\left.18766^{\mathrm{T}}\right)$ & Glacier cryoconite (A) & EF151249 & EF151258 & 20 \\
\hline $\mathrm{A} 10$ & Glacier cryoconite (A) & - & EF151259 & 20 \\
\hline A11 & Glacier cryoconite (A) & AJ853457 & EF151260 & 20 \\
\hline A43 (=CBS 10437) & Glacier cryoconite (A) & EF151250 & EF151261 & 20 \\
\hline AG18 & Mud at glacier foot (A) & EF151251 & EF151262 & 20 \\
\hline
\end{tabular}


Table 2. Phenotypic characteristics that differentiate Rhodotorula psychrophila sp. nov., Rhodotorula psychrophenolica sp. nov. and Rhodotorula glacialis sp. nov.

Strains: 1 , strain $\mathrm{PB} 19^{\mathrm{T}}\left(=\mathrm{CBS} 10440^{\mathrm{T}}\right) ; 2$, strain PB03; 3, strain PB15; 4, strain AG21 ${ }^{\mathrm{T}}\left(=\mathrm{CBS} 10438^{\mathrm{T}}\right) ; 5$, strain A12; 6, strain AG15; 7, strain A19 $\left(=\right.$ CBS $\left.10436^{\mathrm{T}}\right) ; 8$, strain A10; 9, strain A11; 10, strain A43; 11, strain AG18. All strains are positive for the following features: aerobic growth; vegetative reproduction by polar budding; round and convex colonies with entire margins; diazonium blue B reaction; growth in presence of ampicillin $\left(50 \mu \mathrm{g} \mathrm{ml}^{-1}\right)$; assimilation of D-glucose, sucrose, $N$-acetylglucosamine, D-raffinose, potassium-2-ketogluconate, D-mannitol, D-sorbitol, sodium glucuronate, potassium gluconate, nitrate, ethylamide, creatinine and D-tryptophan; urea hydrolysis; $\beta$-glucosidase activity and utilization of phenol, catechol, resorcinol, hydroquinone and benzoate $\left(200 \mu \mathrm{g} \mathrm{ml}^{-1}\right)$ as sole carbon source at $10{ }^{\circ} \mathrm{C}$. All strains are negative for the following features: sexual reproduction; formation of pseudomycelium or true hyphae; pigment formation and slime formation on CMA, MYP agar and R2A agar; production of starch-like compounds; growth in the presence of cycloheximide (200-400 $\left.\mu \mathrm{g} \mathrm{ml}^{-1}\right), 1 \%$ acetic acid, $50 \% \mathrm{D}-$ glucose and $10 \%$ $\mathrm{NaCl}$; activities of $\beta$-galactosidase and protease; presence of glucose fermentation; assimilation of D-galactose, D-lactose, lactic acid, D-arabinose, Dcellobiose, maltose, methyl $\alpha$-D-glucopyranoside, inositol, dulcitol/galactitol, citrate, methanol, ethanol, 2-propanol, D-ribose, glycerol, palatinose, erythritol, levulinic acid, L-sorbose, glucosamine and nitrite and utilization of guaiacol and o-cresol $\left(200 \mu \mathrm{g} \mathrm{ml}^{-1}\right)$ as sole carbon source at $10{ }^{\circ} \mathrm{C}$. ++ , Very good assimilation; +, positive; - , negative; ND, not determined; [Phe $]_{\max }$, maximum phenol concentration fully degraded at $10{ }^{\circ} \mathrm{C}$.

\begin{tabular}{|c|c|c|c|c|c|c|c|c|c|c|c|}
\hline \multirow[t]{2}{*}{ Characteristic } & \multicolumn{3}{|c|}{ R. psychrophila sp. nov. } & \multicolumn{3}{|c|}{$\begin{array}{l}\text { R. psychrophenolica sp. } \\
\text { nov. }\end{array}$} & \multicolumn{5}{|c|}{ R. glacialis sp. nov. } \\
\hline & 1 & 2 & 3 & 4 & 5 & 6 & 7 & 8 & 9 & 10 & 11 \\
\hline Growth temp. range $\left({ }^{\circ} \mathrm{C}\right)$ & $1-15$ & $1-15$ & $1-15$ & $1-20$ & $1-20$ & $1-20$ & $1-20$ & $1-20$ & $1-20$ & $1-20$ & $1-20$ \\
\hline \multicolumn{12}{|l|}{ Carbon assimilation: } \\
\hline L-Arabinose & - & - & - & - & - & - & + & + & + & + & - \\
\hline L-Rhamnose & - & - & - & + & + & + & + & + & + & - & - \\
\hline Salicylate & + & - & ++ & - & ++ & - & ++ & + & - & + & - \\
\hline Trehalose & - & - & - & + & - & - & - & - & - & - & - \\
\hline$[\mathrm{Phe}]_{\max }(\mathrm{mM})$ & 10 & 15 & 10 & 12.5 & ND & 12.5 & 5 & 5 & 5 & 5 & 2.5 \\
\hline
\end{tabular}

Representatives of R. psychrophila sp. nov., as well as of $R$. psychrophenolica sp. nov., were found in geographically distant alpine glacier sites.

\section{Phylogenetic placement}

The phylogenetic tree based on D1/D2 sequence data indicated that two of the novel species, $R$. glacialis sp. nov. and $R$. psychrophila sp. nov., are phylogenetically related (Fig. 1). Moreover they form a well-supported clade with four unidentified isolates of the genus Rhodotorula that show some resemblance to our strains. To our knowledge, these isolates are not described in any publication but, according to the information associated with their sequences at the GenBank database, they were isolated in the Darjeeling Himalaya in India and are psychrophilic. The sister relatives of this entire clade could not be determined with exactitude in our analysis. It seems, however, that other cold-adapted yeasts such as Leucosporidium antarcticum, other as yet undescribed yeasts isolated from the Antarctic and R. psychrophenolica sp. nov., the third novel species described in this report, are relatively close to this group.

Intraspecific variability as revealed by sequence data of the D1/D2 region (Fig. 1) and complete ITS region (data not shown) was very low for $R$. psychrophila sp. nov. (one mismatch for strain PB03 in the ITS region) and R. glacialis sp. nov. (one mismatch for strain A10 in the D1/D2 region and two variable positions in the ITS sequence). Intraspecific sequence polymorphisms were more evident for $R$. psychrophenolica sp. nov., with four variable positions in the D1/D2 region and five variable positions in the ITS sequence.

\section{Latin diagnosis of Rhodotorula psychrophila Margesin et Sampaio sp. nov.}

In agaro MYP post 5 dies ad $15{ }^{\circ} \mathrm{C}$, cellulae ovoideae vel ellipsoidae $(4-8 \times 8-15 \mu \mathrm{m})$, interdum elongatae simile hyphae, binae aut catenae breves (Fig. 2). Flosculi sunt polares. Post 15 dies ad $10-15{ }^{\circ} \mathrm{C}$ in agaro MYP, colonias creameas, rotundas et margine toto. Pseudohyphae et hyphae non formantur. Fermentatio (glucosum) nulla. Sucrosum, $N$-acetylglucosaminum, D-raffinosum, 2-ketogluconicum, Dmannitolum, D-sorbitolum, sodium glucuronatum, D-melezitosum, gluconatum et D-glucosum assimilantur at non D-galactosum, acidum lacticum, L-arabinosum, D-arabinosum, D-cellobiosum, maltosum, trehalosum, D-xylosum, D-ribosum, glycerolum, L-rhamnosum, palatinosum, erythritolum, D-melibiosum, L-sorbosum, acidum levulinicum, glucosaminum, methyl $\alpha$-D-glucopyranosidum, D-lactosum, inositolum, dulcitolum, citratum, methanolum, ethanolum nec 2-propanolum. Nitratum, ethylamidum, kreatininum et D-tryptophanum assimilantur, urea finditur. Non crescit in $1 \%$ acido acetico, $50 \% \mathrm{D}$-glucoso, $10 \% \mathrm{NaCl}$ aut cycloheximido 


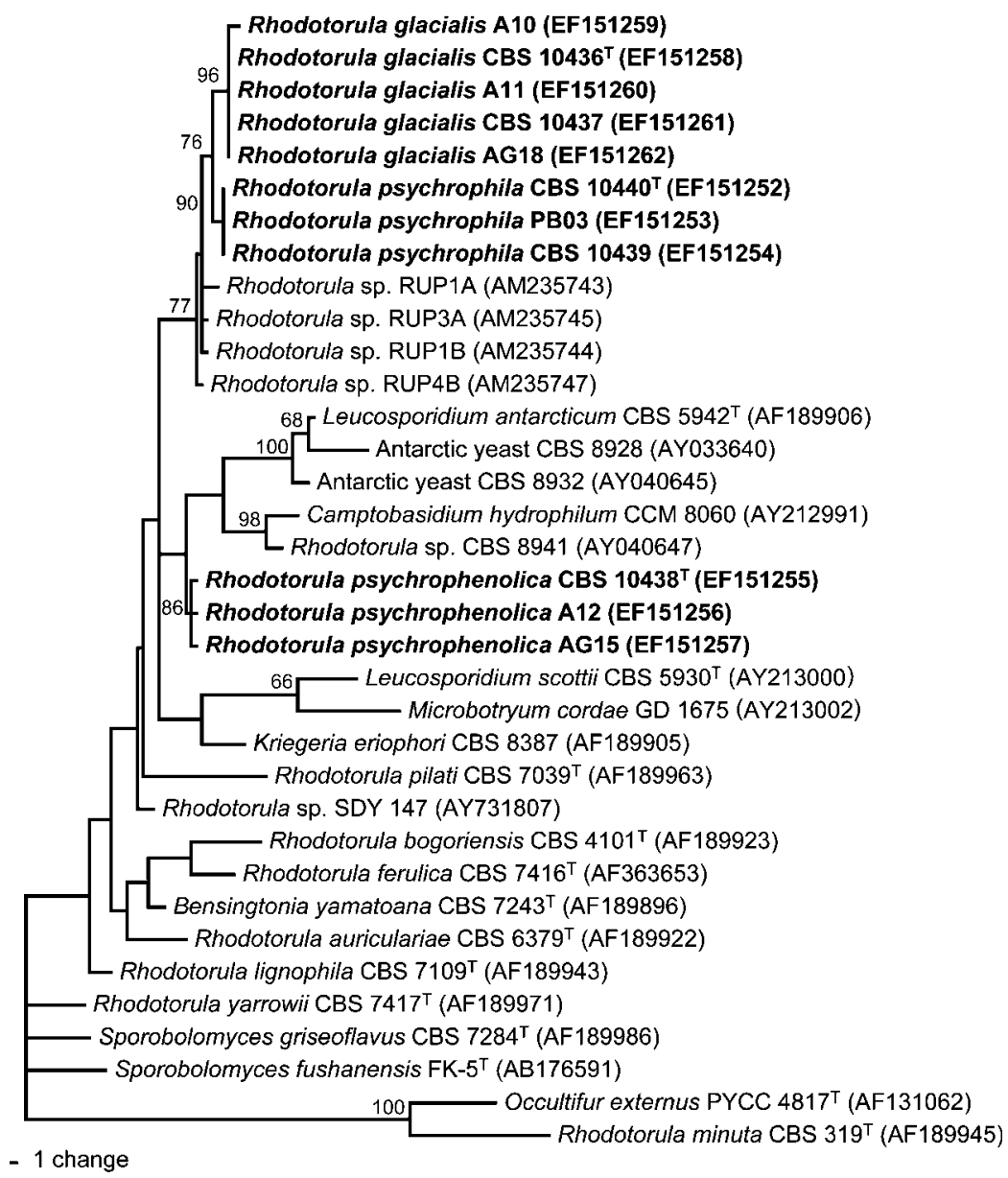

(200-400 $\left.\mu \mathrm{g} \mathrm{ml}^{-1}\right)$; crescit in ampicillino $\left(50 \mu \mathrm{g} \mathrm{ml}^{-1}\right)$. Diazonium caeruleum positivum. Materia amyloidea iodophila non formantur. Maxima temperatura crescentiae: $15{ }^{\circ} \mathrm{C}$, incrementum ad $20{ }^{\circ} \mathrm{C}$ non respondet. Assimilat phenolum, catecholum, resorcinolum, hydroquinonum vel benzoatum $\left(200 \mathrm{mg} \mathrm{l}^{-1}\right)$ ad $10{ }^{\circ} \mathrm{C}$.

Typus stirps $\mathrm{PB} 19^{\mathrm{T}}$ isolatus ex terra, Brenner pass, finis Austria/Italia, depositus in collectione zymotica Centraalbureau voor Schimmelcultures, Utrecht, Nederlandia, CBS $10440^{\mathrm{T}}\left(=\right.$ DSM $\left.18768^{\mathrm{T}}\right)$.
Fig. 1. Phylogenetic tree of Rhodotorula glacialis sp. nov., Rhodotorula psychrophila sp. nov. and Rhodotorula psychrophenolica sp. nov. and related taxa of the Microbotryomycetes. Maximum-parsimony analysis (consensus tree) of an alignment of the D1/ D2 region of the 26S rDNA. The topology was rooted with Occultifur externus and Rhodotorula minuta (Cystobasidiomycetes). Numbers on the branches are bootstrap values (1000 replicates; values below $50 \%$ are not shown). GenBank accession numbers of the sequences are indicated after strain numbers. Bar, 1 change. (a)

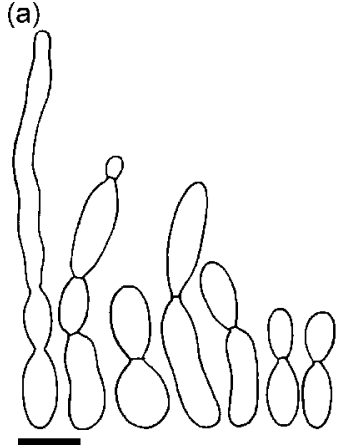

(b)

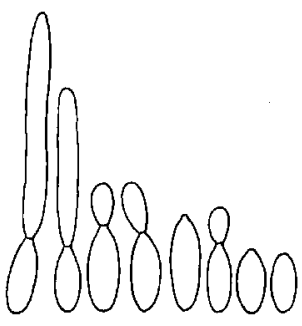

\section{Description of Rhodotorula psychrophila Margesin \& Sampaio sp. nov.}

Rhodotorula psychrophila [psy.chro' phi.la. Gr. adj. psychros relating to cold; Gr. adj. philos relating to loving; N.L. fem. adj. psychrophila referring to cold-loving (psychrophilic) growth].

After 5 days growth on malt-yeast-peptone (MYP) agar at $15{ }^{\circ} \mathrm{C}$, cells are ovoidal to ellipsoidal $(4-8 \times 8-15 \mu \mathrm{m})$, sometimes with hypha-like elongations, and occur in pairs or in small chains (Fig. 2). Budding is polar. After 15 days 
at $10-15{ }^{\circ} \mathrm{C}$, colonies are creamy-white on MYP agar. Colonies are round, convex, with entire margins. No pseudomycelium or true hyphae are formed. Fermentation ability (glucose) is negative. The following carbon compounds are assimilated: sucrose, $\mathrm{N}$-acetylglucosamine, D-raffinose, potassium-2-ketogluconate, D-mannitol, Dsorbitol, sodium glucuronate, D-melezitose, potassium gluconate and D-glucose. No growth occurs on D-galactose, lactic acid, L-arabinose, D-arabinose, D-cellobiose, maltose, trehalose, D-xylose, D-ribose, glycerol, L-rhamnose, palatinose, erythritol, D-melibiose, L-sorbose, levulinic acid, glucosamine, methyl $\alpha$-D-glucopyranoside, D-lactose, inositol, dulcitol, citrate, methanol, ethanol or 2-propanol. Assimilation of the nitrogen compounds nitrate, ethylamide, creatinine and D-tryptophan is positive. Urea hydrolysis is positive; nitrite is not utilized. No growth occurs in the presence of $1 \%$ acetic acid, $50 \%$ D-glucose, $10 \% \mathrm{NaCl}$ or cycloheximide $\left(200-400 \mu \mathrm{g} \mathrm{ml}^{-1}\right)$. Growth occurs in the presence of ampicillin $\left(50 \mu \mathrm{g} \mathrm{ml} \mathrm{m}^{-1}\right)$. Diazonium blue B reaction is positive. No starch-like substances are produced. Growth occurs at $15{ }^{\circ} \mathrm{C}$, but not at $20{ }^{\circ} \mathrm{C}$. Phenol, catechol, resorcinol, hydroquinone or benzoate $\left(200 \mathrm{mg} \mathrm{l}^{-1}\right)$ are utilized as sole carbon sources at $10{ }^{\circ} \mathrm{C}$. Phenol is fully degraded (up to $10 \mathrm{mM}$ ) as the sole carbon source at $10{ }^{\circ} \mathrm{C}$.

The type strain, $\mathrm{PB} 19^{\mathrm{T}}\left(=\mathrm{DSM} 18768^{\mathrm{T}}=\mathrm{CBS} 10440^{\mathrm{T}}\right)$ was isolated from the soil of a railway area at the Brenner pass, on the Austria/Italy border. Other strains, PB03 and PB15, were isolated from the sediment of an oil-shale mine in Seefeld, Austria.

\section{Latin diagnosis of Rhodotorula psychrophenolica Margesin et Sampaio sp. nov.}

In agaro MYP post 5 dies ad $15{ }^{\circ} \mathrm{C}$, cellulae ovoideae vel ellipsoidae $(3-4 \times 9-15 \mu \mathrm{m})$, singulae vel binae vel catenae breves (Fig. 2). Flosculi sunt polares. Post 15 dies ad 10$15{ }^{\circ} \mathrm{C}$ in agaro MYP, colonias creameas, rotundas et margine toto. Pseudohyphae et hyphae non formantur. Fermentatio (glucosum) nulla. Sucrosum, N-acetylglucosaminem, Draffinosum, 2-ketogluconatum, D-mannitolum, D-sorbitolum, L-rhamnosum, sodium glucuronatum, potassium gluconatum et $\mathrm{D}$-glucosum assimilantur at non D-galactosum, acidum lacticum, L-arabinosum, D-arabinosum, D-cellobiosum, maltosum, methyl $\alpha$-D-glucopyranosidum, D-lactosum, inositolum, dulcitolum, citratum, methanolum, ethanolum, 2propanolum, D-ribosum, glycerolum, palatinosum, erythritolum, D-melibiosum, D-melezitosum, L-sorbosum, acidum levulinicum nec glucosaminum. Nitratum, ethylamidum, kreatininum et D-tryptophanum assimilantur, urea finditur. Non crescit in $1 \%$ acido acetico, $50 \%$ D-glucoso, $10 \% \mathrm{NaCl}$ aut cycloheximido $\left(200-400 \mu \mathrm{g} \mathrm{ml}^{-1}\right)$; crescit in ampicillino $\left(50 \mu \mathrm{g} \mathrm{ml}^{-1}\right)$. Diazonium caeruleum positivum. Materia amyloidea iodophila non formantur. Maxima temperatura crescentiae: $20{ }^{\circ} \mathrm{C}$, incrementum ad $25{ }^{\circ} \mathrm{C}$ non respondet. Assimilat phenolum (12.5 mM), catecholum, resorcinolum, hydroquinonum vel benzoatum $\left(200 \mathrm{mg} \mathrm{l}^{-1}\right.$ ) ad $10{ }^{\circ} \mathrm{C}$.
Typus stirps AG $21^{\mathrm{T}}$ isolatus ex caeno glacialis, Etendard Glacier, France, depositus in collectione zymotica Centraalbureau voor Schimmelcultures, Utrecht, Nederlandia, CBS $10438^{\mathrm{T}}\left(=\mathrm{DSM} 18767^{\mathrm{T}}\right)$.

\section{Description of Rhodotorula psychrophenolica Margesin \& Sampaio sp. nov.}

Rhodotorula psychrophenolica (psy.chro.phen.o'li.ca. Gr. adj. psychros relating to cold; N.L. fem. adj. phenolica relating to phenol degradation; N.L. fem. adj. psychrophenolica relating to cold-adapted phenol-degrading yeast).

After 5 days growth on MYP agar at $15{ }^{\circ} \mathrm{C}$, cells are ellipsoidal $(3-4 \times 9-15 \mu \mathrm{m})$ and occur singly, in pairs (mainly) or in small chains (Fig. 2). Budding is polar. After 15 days at $10-15{ }^{\circ} \mathrm{C}$, colonies are creamy-white on MYP agar. Colonies are round, convex, with entire margins. No pseudomycelium or true hyphae are formed. Fermentation ability (glucose) is negative. The following carbon compounds are assimilated: sucrose, $\mathrm{N}$-acetylglucosamine, D-raffinose, potassium-2-ketogluconate, D-mannitol, Dsorbitol, L-rhamnose, sodium glucuronate, potassium gluconate and D-glucose. No growth occurs on D-galactose, lactic acid, L-arabinose, D-arabinose, D-cellobiose, maltose, methyl $\alpha$-D-glucopyranoside, D-lactose, inositol, dulcitol, citrate, methanol, ethanol, 2-propanol, D-ribose, glycerol, palatinose, erythritol, D-melibiose, D-melezitose, L-sorbose, levulinic acid or glucosamine. Assimilation of the nitrogen compounds nitrate, ethylamide, creatinine and D-tryptophan is positive. Urea hydrolysis is positive. Nitrite is not utilized. No growth occurs in the presence of $1 \%$ acetic acid, $50 \%$ D-glucose, $10 \% \mathrm{NaCl}$ or cycloheximide (200$400 \mu \mathrm{g} \mathrm{ml}^{-1}$ ). Growth occurs in the presence of ampicillin $\left(50 \mu \mathrm{g} \mathrm{ml}^{-1}\right)$. Diazonium blue $\mathrm{B}$ reaction is positive. No starch-like substances are produced. Growth occurs at $20{ }^{\circ} \mathrm{C}$, but not at $25{ }^{\circ} \mathrm{C}$. Phenol, catechol, resorcinol, hydroquinone or benzoate $\left(200 \mathrm{mg} \mathrm{l}^{-1}\right)$ are utilized as the sole carbon source at $10^{\circ} \mathrm{C}$. Phenol is fully degraded (up to $12.5 \mathrm{mM}$ ) as the sole carbon source at $10{ }^{\circ} \mathrm{C}$.

The type strain, AG2 $1^{\mathrm{T}}\left(\mathrm{DSM} 18767^{\mathrm{T}}=\mathrm{CBS} 10438^{\mathrm{T}}\right)$ was isolated from mud in the thawing zone at the glacier foot of the Etendard Glacier, France. Additional strains were isolated from mud in the thawing zone of the Stubaier Glacier, Austria (AG15) and from glacier cryoconite collected from the Stubaier Glacier, Austria (A12).

\section{Latin diagnosis of Rhodotorula glacialis Margesin et Sampaio sp. nov.}

In agaro MYP post 5 dies ad $15{ }^{\circ} \mathrm{C}$, cellulae ellipsoidae (3$5 \times 8-15 \mu \mathrm{m}$ ), singulae vel binae vel catenae breves (Fig. 2 ). Flosculi sunt polares. Post 15 dies ad $10-15{ }^{\circ} \mathrm{C}$ in agaro MYP, colonias creameas, rotundas et margine toto. Pseudohyphae et hyphae non formantur. Fermentatio (glucosum) nulla. Sucrosum, $N$-acetylglucosaminum, D-raffinosum, 2-ketogluconatum, D-mannitolum, D-sorbitolum, sodium 
glucuronatum, potassium gluconatum et $\mathrm{D}$-glucosum assimilantur at non D-galactosum, acidum lacticum, D-arabinosum, D-cellobiosum, maltosum, trehalosum, methyl $\alpha$-D-glucopyranosidum, D-lactosum, inositolum, dulcitolum, citratum, methanolum, ethanolum, 2-propanolum, D-ribosum, glycerolum, palatinosum, erythritolum, L-sorbosum, acidum levulinicum nec glucosaminum. Nitratum, ethylamidum, kreatininum et D-tryptophanum assimilantur; urea finditur. Non crescit in $1 \%$ acido acetico, $50 \%$ D-glucoso, $10 \% \mathrm{NaCl}$ aut cycloheximido $\left(200-400 \mu \mathrm{g} \mathrm{ml}^{-1}\right)$; crescit in ampicillino $\left(50 \mu \mathrm{g} \mathrm{ml}^{-1}\right)$. Diazonium caeruleum positivum. Materia amyloidea iodophila non formantur. Maxima temperatura crescentiae: $20{ }^{\circ} \mathrm{C}$, incrementum ad $25{ }^{\circ} \mathrm{C}$ non respondet. Assimilat phenolum ( $5 \mathrm{mM})$, catecholum, resorcinolum, hydroquinonum vel benzoatum $\left(200 \mathrm{mg}^{-1}\right)$ ad $10{ }^{\circ} \mathrm{C}$.

Typus stirps $\mathrm{A} 19^{\mathrm{T}}$ isolatus ex cryoconito glacialis, Stubaier Glacier, Austria, depositus in collectione zymotica Centraalbureau voor Schimmelcultures, Utrecht, Nederlandia, CBS $10436^{\mathrm{T}}\left(=\mathrm{DSM} 18766^{\mathrm{T}}\right)$.

\section{Description of Rhodotorula glacialis Margesin \& Sampaio sp. nov.}

Rhodotorula glacialis (gla.cia'lis. L. fem. adj. glacialis referring to the frozen, icy environment from which the strains were isolated).

After 5 days growth on MYP agar at $15{ }^{\circ} \mathrm{C}$, cells are ellipsoidal $(3-5 \times 8-15 \mu \mathrm{m})$ and occur singly, in pairs (mainly) or in small chains (Fig. 2). Budding is polar. After 15 days at $10-15{ }^{\circ} \mathrm{C}$, colonies are creamy-white on MYP agar. Colonies are round, convex, with entire margins. No pseudomycelium or true hyphae are formed. Fermentation ability (glucose) is negative. The following carbon compounds are assimilated: sucrose, $\mathrm{N}$-acetylglucosamine, D-raffinose, potassium-2-ketogluconate, D-mannitol, Dsorbitol, sodium glucuronate, potassium gluconate and D-glucose. No growth occurs on D-galactose, lactic acid, D-arabinose, D-cellobiose, maltose, trehalose, methyl $\alpha$-Dglucopyranoside, D-lactose, inositol, dulcitol, citrate, methanol, ethanol, 2-propanol, D-ribose, glycerol, palatinose, erythritol, L-sorbose, levulinic acid or glucosamine. Assimilation of the nitrogen compounds nitrate, ethylamide, creatinine and D-tryptophan is positive. Urea hydrolysis is positive. Nitrite is not utilized. No growth occurs in the presence of $1 \%$ acetic acid, $50 \%$ D-glucose, $10 \% \mathrm{NaCl}$ or cycloheximide $\left(200-400 \mu \mathrm{g} \mathrm{ml}^{-1}\right)$. Growth occurs in the presence of ampicillin $\left(50 \mu \mathrm{g} \mathrm{ml} \mathrm{m}^{-1}\right)$. Diazonium blue B reaction is positive. No starch-like substances are produced. Growth occurs at $20{ }^{\circ} \mathrm{C}$, but not at $25^{\circ} \mathrm{C}$. Phenol, catechol, resorcinol, hydroquinone or benzoate $\left(200 \mathrm{mg} \mathrm{l}^{-1}\right)$ are utilized as the sole carbon source at $10{ }^{\circ} \mathrm{C}$. Phenol is fully degraded (up to $5 \mathrm{mM}$ ) as the sole carbon source at $10{ }^{\circ} \mathrm{C}$.
The type strain, $\mathrm{A} 19^{\mathrm{T}}\left(=\mathrm{DSM} 18766^{\mathrm{T}}=\mathrm{CBS} 10436^{\mathrm{T}}\right)$, was isolated from glacier cryoconite collected on the Stubaier Glacier, Austria. Additional strains were isolated from glacier cryoconite (A10, A11, A43) or from mud in the thawing zone at the glacier foot collected on the Stubaier Glacier, Austria (AG18).

\section{ACKNOWLEDGEMENTS}

R. M. thanks Karin Weber for skilful technical assistance and A. M. Gounot for providing strains AG15, AG18 and AG21.

\section{REFERENCES}

Barnett, J. A., Payne, R. W. \& Yarrow, D. (2000). Yeasts: Characteristics and Identification, 3rd edn. Cambridge, UK: Cambridge University Press.

Bauer, R., Begerow, D., Sampaio, J. P., Weiß, M. \& Oberwinkler, F. (2006). The simple-septate basidiomycetes: a synopsis. Mycol Prog 5, 41-66.

Bergauer, P., Fonteyne, P. A., Nolard, N., Schinner, F. \& Margesin, R. (2005). Biodegradation of phenol and phenol-related compounds by psychrophilic and cold-tolerant alpine yeasts. Chemosphere 59, 909-918.

Fell, J. W., Boekhout, T., Fonseca, A. \& Sampaio, J. P. (2001). Basidiomycetous yeasts. In The Mycota. Systematics and Evolution Vol. VII, Part B, pp. 1-37. Edited by K. Esser \& P.A. Lemke. Berlin, Germany: Springer Verlag.

Felsenstein, J. (1985). Confidence limits on phylogenies: an approach using the bootstrap. Evolution 39, 783-791.

Margesin, R., Zacke, G. \& Schinner, F. (2002). Characterization of heterotrophic microorganisms in alpine glacier cryoconite. Arct Antarct Alp Res 34, 88-93.

Margesin, R., Gander, S., Zacke, G., Gounot, A. M. \& Schinner, F. (2003). Hydrocarbon degradation and enzyme activities of coldadapted bacteria and yeasts. Extremophiles 7, 451-458.

Margesin, R., Fonteyne, P. A. \& Redl, B. (2005). Low-temperature biodegradation of high amounts of phenol by Rhodococcus spp. and basidiomycetous yeasts. Res Microbiol 156, 68-75.

Morita, R. Y. (1975). Psychrophilic bacteria. Bacteriol Rev 39, 144-167. O’Donnell, K., Cigelnik, E., Weber, N. S. \& Trappe, J. M. (1997). Phylogenetic relationships among ascomycetous truffles and the true and false morels inferred from $18 \mathrm{~S}$ and $28 \mathrm{~S}$ rDNA sequence analysis. Mycologia 89, 48-65.

Sampaio, J. P. (1999). Utilization of low molecular weight aromatic compounds by heterobasidiomycetous yeasts: taxonomic implications. Can J Microbiol 45, 491-512.

Sampaio, J. P. (2004). Diversity, phylogeny and classification of basidiomycetous yeasts. In Frontiers in Basidiomycete Mycology, pp. 49-80. Edited by R. Agerer, P. Blanz \& M. Piepenbring. Germany: IHW-Verlag.

Sampaio, J. P., Gadanho, M., Bauer, R. \& Weiß, M. (2003). Taxonomic studies in the Microbotryomycetidae: Leucosporidum golubevii sp. nov., Leucosporidiella gen. nov. and the new orders Leucosporidiales and Sproidiobolales. Mycol Prog 2, 53-68.

Swofford, D. L. (2001). PAUP*: Phylogenetic analysis using parsimony (and other methods). Sunderland, MA: Sinauer Associates. 